\title{
Deletion of Mid1, a putative stretch-activated calcium channel in Claviceps purpurea, affects vegetative growth, cell wall synthesis and virulence \\ Correspondence \\ Paul Tudzynski \\ tudzyns@uni-muenster.de \\ Received 13 May 2009 \\ Revised 14 September 2009 \\ Accepted 15 September 2009

\author{
Jörg Bormann and Paul Tudzynski
} \\ Institut für Botanik, Westfälische Wilhelms-Universität Münster, Schloßgarten 3, D-48149 Münster, Germany

\begin{abstract}
The putative Claviceps purpurea homologue of the Saccharomyces cerevisiae stretch-activated calcium ion channel Mid1 was investigated for its role in vegetative growth, differentiation and pathogenicity on rye (Secale cereale). Gene replacement mutants of Cl. purpurea mid1 were not affected in polar growth and branching in axenic culture but showed a significantly reduced growth rate. The growth defect could not be complemented by $\mathrm{Ca}^{2+}$ supplementation, in contrast to mid1 mutants in yeast, but the altered sensitivity of the mutants to changes in external and internal $\mathrm{Ca}^{2+}$ concentrations indicates some role of Mid1 in $\mathrm{Ca}^{2+}$ homeostasis. The major effect of mid1 deletion, however, was the complete loss of virulence: infected rye plants showed no disease symptoms at all. Detailed analyses of in vitro-infected rye ovaries demonstrated that the $\Delta$ mid1 mutants had multiple apical branches and were unable to infect the host tissue, suggesting that Mid1 is essential for generating the necessary mechanical force for penetration. This is believed to be the first report of an essential role for a Mid1 homologue in the virulence of a plantpathogenic fungus.
\end{abstract}

\section{INTRODUCTION}

The phytopathogenic biotrophic ascomycete Claviceps purpurea (Fries ex Fries) Tulasne parasitizes a large number of Poaceae species (Tudzynski \& Scheffer, 2004). It colonizes ovaries of its main host, rye (Secale cereale), by penetrating the cuticle and growing through the ovarian tissue in a strictly directed and unbranched manner until it reaches the vascular bundles. By tapping into the vascular bundles, the fungus assures a stable nutrition supply. This is a prerequisite for the subsequent colonization of the entire ovary. During this process the fungus produces masses of conidia which are secreted in a viscous fluid called honeydew. Spores are dispersed to other blooming florets mainly zoochorically and hydrochorically. The period of conidia formation ends when sclerotium formation is initiated. The sclerotia represent resting structures consisting of a solid plectenchymatous structure of pigmented storage cells (Tenberge, 1999). They contain the so-called ergot alkaloids, which represent a class of pharmacologically important mycotoxins (Schardl et al., 2006).

Abbreviations: CW calcofluor white; FITC-WGA, fluorescein isothiocyanate-labelled wheatgerm agglutinin.

The GenBank/EMBL/DDBJ accession number for the mid1 gene of Claviceps purpurea is FM945328.

Five supplementary figures are available with the online version of this paper.
The fungus grows mainly intercellularly and therefore decomposes the middle lamella between the plant cells. This lamella predominantly consists of pectin; degradation of pectin by fungal polygalacturonases is essential for full pathogenicity (Oeser et al., 2002). It is possible that $\mathrm{Ca}^{2+}$ complexed in this pectin could act as a trail for the hyphae on their way through the ovary. A tip-high gradient of cytoplasmic calcium $\left(\left[\mathrm{Ca}^{2+}\right]_{\text {cyt. }}\right.$. has been observed in a wide range of eukaryotes that grow in a polarized and oriented manner, including fungal hyphae (Jackson \& Heath, 1993; Silverman-Gavrila \& Lew, 2003), neurons (Mattson, 1999), and pollen tubes and root hairs of vascular plants (Hepler et al., 2001; Malhó \& Trewavas, 1996; Pierson et al., 1994); Cl. purpurea may possess a similar gradient. $\mathrm{Ca}^{2+}$ is one of the main signal mediators in eukaryotic cells and regulates a wide range of cellular processes such as gene expression (Yoshimoto et al., 2002) and cytoskeleton rearrangements (Torralba \& Heath, 2001), e.g in response to external stimuli and stresses (Cyert, 2003; Kraus \& Heitman, 2003).

One of the key players in $\mathrm{Ca}^{2+}$ homeostasis and generation of $\left[\mathrm{Ca}^{2+}\right]_{\text {cyt. }}$ gradients is the $\mathrm{Ca}^{2+}$-permeable, stretchactivated nonselective cation channel Mid1. It seems to mediate $\mathrm{Ca}^{2+}$ uptake as a result of membrane distension, as shown in several polar-growing organisms, including Saprolegnia ferax (Garrill et al., 1993) and Candida albicans (Watts et al., 1998), and in roots of Arabidopsis thaliana (Nakagawa et al., 2007). 
The role of Mid1 in different organisms is highly variable. While in yeast Mid1 is essential for viability upon response to mating pheromone (Iida et al., 1994), it has no impact on mating in Neurospora crassa (Lew et al., 2008). The tiphigh $\mathrm{Ca}^{2+}$ gradient necessary for polar growth (Jackson \& Heath, 1993; Silverman-Gavrila \& Lew, 2003) is obviously generated in different ways: in S. ferax tip-localized $\mathrm{Ca}^{2+}$ channels establish and maintain the gradient (Garrill et al., 1993), whereas in N. crassa the $\mathrm{Ca}^{2+}$ originates mainly from intracellular storage compartments (Levina et al., 1995; Silverman-Gavrila \& Lew, 2002). In the latter case it is proposed that Mid1 mainly plays a role in $\mathrm{Ca}^{2+}$ homoestasis (Lew et al., 2008).

In $\mathrm{Ca}$. albicans Mid 1 forms a complex with the voltagegated $\mathrm{Ca}^{2+}$ channel Cch1 (Brand et al., 2007); Mid1 is probably activated by membrane stretching and mediates the subsequent opening of the Cch1 channel, thus leading to localized $\mathrm{Ca}^{2+}$ influx. A reduced growth rate has been observed in mid1, cch1 and the double knockout mutant, whereas the extension rate of hyphae remains unaffected. In addition, the ability of mutants to reorient growth when reaching a ridge is significantly reduced. On the other hand there are indications that, in Saccharomyces cerevisiae, the Mid1 channel itself is able to form a functional $\mathrm{Ca}^{2+}$ channel independent of Cch1 when heterologously expressed in hamster ovary cells (Kanzaki et al., 1999).

Deletion of the cch1 homologue in Gibberella zeae leads to reduced growth rate and a complete loss of ascospore discharge (Hallen \& Trail, 2008). So far not much is known about the role of Mid1 homologues in plant-pathogenic fungi. A wide-scale silencing approach on several $\mathrm{Ca}^{2+}$ signalling related proteins in Magnaporthe grisea (Nguyen et al., 2008) revealed a minor role for both Mid1 and Cch1 in both pathogenicity and growth rate. Since this knockdown approach only diminishes the expression of both proteins compared to the wild-type, the results can only hint at the influence of these $\mathrm{Ca}^{2+}$ channels during plant infection.

Here we show that deletion of the mid1 homologue in $\mathrm{Cl}$. purpurea has a severe impact on pathogenicity, development and morphology.

\section{METHODS}

Strains and cultures. A derivative strain of Claviceps purpurea 20.1 (Hüsgen et al., 1999), itself derived from the T5 strain isolated from Secale cereale, was used for generation of mutants and as reference

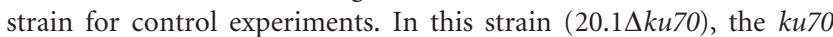
gene responsible for nonhomologous end joining (NHEJ) had been deleted (Haarmann et al., 2008), drastically increasing the rate of homologous integration from $1-2 \%$ to $50-60 \%$. For strain conservation, DNA isolation and spore production mycelia were grown on the complete medium BII (Esser \& Tudzynski, 1978) or Mantle medium (MM; Mantle \& Nisbet, 1976). For RNA isolation, submerged cultures of BII and MM were used. Escherichia coli strain TOP10 $\mathrm{F}^{\prime}$ was used for all cloning experiments. E. coli strain LE392 was used for reproduction of $\mathrm{Cl}$. purpurea genomic lambda clones.
Nucleic acid extraction and analysis. Standard recombinant DNA methods were performed according to Ausubel et al. (1987) and Sambrook et al. (1989). Genomic DNA of Cl. purpurea was extracted from lyophilized mycelium as described by Cenis (1992). RNA for RTPCR and Northern hybridization was isolated using the RNAgents total RNA isolation system from Promega. For RT-PCR $1 \mu \mathrm{g}$ of total RNA was taken for cDNA synthesis using the oligo(dT) ${ }_{12-18}$ primer and SuperScript II reverse transcriptase (Invitrogen) according to the manufacturer's instructions. PCR was performed in accordance with Sambrook et al. (1989), using Biotherm polymerase (Sigma). Primers were synthesized by Operon Biotechnologies. PCR fragments were cloned using the Invitrogen pCR2.1-TOPO-cloning kit. Southern and Northern blotting were performed on Amersham Hybond-N+ membrane according to the manufacturer's instructions. The membranes were hybridized with $\left[\alpha^{32}-\mathrm{P}\right] \mathrm{dCTP}$-marked probes. Probes of genes were amplified by PCR. DNA sequencing was done (i) using the Thermo Sequenase fluorescent labelled primer cycle sequencing kit with 7deaza-dGTP (Amersham) and a LI-COR DNA sequencer models 4000 and 4200 (MWG Biotech) and (ii) using the Big Dye Terminator v3.1 sequencing kit (Applied Biosystems). For the latter method 200$250 \mathrm{ng}$ plasmid DNA was applied. After the PCR the samples were purified by column chromatography and sequenced in an ABI Prism capillary sequencer (model 3730). Sequence alignments, editing and organization were done using either Lasergene software (DNAStar) or Vector NTI 10.3.0 (Invitrogen). Homology searches were performed with BLAST at NCBI (Altschul et al., 1990).

Cloning of mid1 and generation of replacement and complementation vector. A 918 bp fragment was obtained from a cDNA clone of a Cl. purpurea EST library (Oeser et al., 2009) which showed a high similarity to mid1 in Neurospora crassa, Aspergillus fumigatus and Schizosaccharomyces pombe. In order to obtain additional sequence information this fragment was used as a probe to screen a genomic library of $\mathrm{Cl}$. purpurea strain T5 (Smit \& Tudzynski, 1992) by plaque filter hybridization (Sambrook et al., 1989). Of the $40000 \lambda$ clones screened, 12 hybridized with the cDNA fragment. Three of these were further purified and subsequently analysed. After isolation from phages, DNA was digested with BamHI, EcoRI, HindIII, SphI, $X b a \mathrm{I}$ and $X h o I$. Fragments that showed positive hybridization with the midl probe in the Southern analysis were cloned into pUC19 and subsequently sequenced. Two BamHI fragments of about $1 \mathrm{~kb}$ and $2.5 \mathrm{~kb}$ and subclones from a $5 \mathrm{~kb} S p h \mathrm{I}$ fragment gave rise to a total of $4862 \mathrm{bp}$ of coding sequence and flanking region. Using this information, a replacement vector was constructed using primers 1 and 2 for amplification of $1341 \mathrm{bp}$ of the designated left flank and primers 3 and 4 for amplification of $835 \mathrm{bp}$ of the designated right flank of the replacement vector, respectively (Table 1 and Supplementary Fig. S1a). Both fragments were cloned into the pCR2.1-TOPO vector, sequenced using primers 15 and 16 (Table 1), excised using the restriction sites (HindIII/BglII and XbaI/SacII, respectively) included in the $5^{\prime}$-ends of the primers ( 1 and 2 for the left flank and 3 and 4 for the right flank), and subsequently cloned upstream and downstream, respectively, of the phleomycin-resistance cassette of plasmid pAN81-UM (Müller et al., 1997). Digestion of p $\Delta$ midl with SacII and HindIII released a 5521 bp fragment, which was used to transform the $C l$. purpurea strain $20.1 \Delta k u 70$.

For complementation of $\Delta$ mid1 mutant strains, the full-length coding region of midl and an $850 \mathrm{bp}$ segment upstream of the start codon were amplified from genomic DNA of $\mathrm{Cl}$. purpurea strain $20.1 \Delta k u 70$ using primers 11 and 12 , respectively. The fragment was cloned into pCR2.1-TOPO vector, sequenced using primers 15 and 16 and subsequently excised using the ApaI/HindIII sites included in the $5^{\prime}$ ends of primers 11 and 12, respectively. The ApaI/HindIII fragment was cloned into vector pAN71-UM (Müller et al., 1997), harbouring a hygromycin-resistance cassette, giving rise to the plasmid $\mathrm{p} 7 \mathrm{MeP}$. In order to achieve a recombination event in loco, a right flank 
Table 1. PCR primers used in this study

\begin{tabular}{|ll|}
\hline No. & \multicolumn{1}{c|}{ Sequence $\left(\mathbf{5}^{\prime} \rightarrow \mathbf{3}^{\prime}\right)$} \\
\hline 1 & AGATCTCCGACGCCGTTTGACCA \\
2 & TGGCTGTTCAAGCTTCCGTTCC \\
3 & TCTAGATGAGACTCGGAAAGGCAGAAGATG \\
4 & CCGCGGACACGTGGGCAG \\
5 & ATGCGCCGAATATTGAGGATGACT \\
6 & GCACCGGGGGAGGCTGAC \\
7 & GCGTCTTCAAGTTCATTTTCTC \\
8 & GTTGTGACAGGACGAGGCTCCTCG \\
9 & CCTATGAGTCGTTTACCCAGAATG \\
10 & AGGCGACGCTCAGGAC \\
11 & GGGCCCGAGGTGCCTGACTGGG \\
12 & AAGCTTTCACCACACCACCAACAAGCC \\
13 & TCTAGATGAGACTCGGAAAGGCAGAAGATG \\
14 & CCGCGGACACGTGGGCAG \\
15 & GAGCGGATAACAATTTCACACAGG \\
16 & AGGGTTTCCCAGTCACGACGGTT \\
17 & GGGGCGTCGGTTTCCACTATCG \\
\hline
\end{tabular}

homologous to the right flank of the deletion vector was introduced. This flank was amplified using primers 13 and 14, digested using the artificial restriction sites included in the $5^{\prime}$-ends of the primers (XbaI, NotI), and ligated into vector p7MeP, yielding complementation vector $\mathrm{p} 7 \mathrm{cmid} 1$.

Fungal transformation. Protoplast transformation was performed as described previously (Jungehülsing et al., 1994). Protoplasts were generated using a mixture of lysing enzymes from Trichoderma harzianum and Driselase (both Sigma). For the gene replacement transformation, protoplasts were transformed with the fragment excised from p $\Delta$ mid 1 using SacII and HindIII. Complementation was done by transformation with the fragment excised from $\mathrm{p} 7 \mathrm{cmid} 1$ using ApaI and NotI. After transformation, protoplasts were mixed with $20 \mathrm{ml}$ modified $\mathrm{BII}$ ( $\mathrm{pH} \mathrm{8}$, without $\mathrm{FeSO}_{4}, 20 \%$, w/v, sucrose) and poured into $92 \mathrm{~mm}$ Petri dishes. After $24 \mathrm{~h}$ incubation, a selective overlay of $10 \mathrm{ml}$ BII medium containing either $100 \mu \mathrm{g}$ phleomycin $\mathrm{ml}^{-1}$ (reaching a final concentration of $33 \mu \mathrm{g} \mathrm{ml}^{-1}$ on the transformation plates) for the midl knockout or $1.5 \mathrm{mg}$ hygromycin $\mathrm{ml}^{-1}$ (final concentration of $0.5 \mathrm{mg} \mathrm{ml}^{-1}$ on the transformation plate) for the complementation was applied. Resistant colonies were transferred to selection plates containing either $0.5 \mathrm{mg}$ hygromycin $\mathrm{ml}^{-1}$ or $100 \mu \mathrm{g}$ phleomycin $\mathrm{ml}^{-1}$, depending on the resistance that was transferred. The gene replacement transformation was subsequently analysed by PCR for homologous integration of the fragment. To obtain homokaryotic knockout transformants, single-spore isolation was performed.
Primer pairs used to identify transformants with homologous integration of the $5^{\prime}$ flank were 7 and 8 , and for the $3^{\prime}$ flank 9 and 10 (Table 1 and Supplementary Fig. S1a). Complete deletion of mid1 in the transformants was confirmed with the primer pair 5 and 6 (Table 1 and Supplementary Fig. S1a).

Plate assays. The base medium for all plate assays was MM. For each test at least five plates were prepared for each strain. Unless indicated elsewhere, the supplements were added prior to autoclaving. The $\mathrm{pH}$ was adjusted to 5.2 and a mycelial plug of either the reference strain $20.1 \Delta k u 70$ or a mutant strain was placed in the middle of the plate.

For growth assays plates were prepared with agar of concentrations $1 \%, 1.5 \%, 2 \%$ and $3 \%\left(\right.$ all w/v). To assess the role of elevated $\mathrm{Ca}^{2+}$ in the medium, MM was supplemented with 5, 10, 30, 40, 50, 100 and $200 \mathrm{mM} \mathrm{CaCl}$. $\mathrm{MM}$ is usually supplemented with $4.2 \mathrm{mM}$ $\mathrm{Ca}\left(\mathrm{NO}_{3}\right)_{2}$. For analysis of the effect of $\mathrm{Ca}^{2+}$ depletion, the medium was prepared without $\mathrm{CaCl}_{2}$, and EGTA was added at concentrations of 1,5 and $10 \mathrm{mM}$. Cell wall stress was tested with calcofluor white (CW) added in concentrations of $0.1,0.25,0.5,0.75$ and $1 \mathrm{mg} \mathrm{ml}^{-1}$ and Congo red $\left(2 \mathrm{mg} \mathrm{ml}^{-1}\right)$, both after sterile filtration. The influence of osmotic stress was tested by adding $\mathrm{NaCl}$ at concentrations of $10,50,100,500 \mathrm{mM}$ and $1 \mathrm{M} . \mathrm{Mg}^{2+}$ was added as $\mathrm{MgSO}_{4}$ at a concentration of $66 \mathrm{mM}$.

Measurements of the colony diameter were done after 14 days of growth under standard conditions, unless stated otherwise. Statistical analysis of group differences was done by use of the non-parametric Mann-Whitney $U$-test.

Pathogenicity tests. Rye plants were cultivated in growth chambers as described by Smit \& Tudzynski (1992). Florets of blooming ears (3040 per ear) were inoculated either with $5 \mu$ of conidial suspension containing $2 \times 10^{6}$ viable spores $\mathrm{ml}^{-1}$ collected from MM agar, as described by Tenberge et al. (1996), or with a suspension of mycelium rubbed off an agar plate. Immediately after treatment the ears were covered with paper bags equipped with a cellophane window that allowed observation. In vitro pathogenicity tests were performed according to Scheffer \& Tudzynski (2006). Isolated rye ovaries were cultivated on Hoagland medium (Hoagland \& Arnon, 1950), modified for barley shoot culture (Scheffer \& Tudzynski, 2006) and inoculated with a spore suspension $\left(2 \times 10^{6}\right.$ spores $\left.\mathrm{ml}^{-1}\right)$ or mycelial suspension. At different time points the ovaries were dissected and stained with $\mathrm{KOH}$ /aniline blue (Currier \& Strugger, 1956). This method allows detailed analysis of early infection stages (1-10 days post-inoculation; days p.i.) by epifluorescence microscopy (Hood \& Shew, 1996). For scanning electron microscopy, ovaries were inoculated with each strain as described above. At 3 days p.i., samples were aldehyde fixed and dehydrated in an ethanol series as described by Giesbert et al. (1998). Samples were critical-point-dried (Emitech K850 critical point dryer), gold-sputtered (Emitech vacuum sputter device K550x) and examined with a Hitachi S.3000N scanning electron microscope at $15 \mathrm{kV}$.

Fig. 1. Amino acid sequence alignment of Mid1 orthologues of different filamentous fungi and yeasts: Neurospora crassa (CAD70927) (German Neurospora genome project, 2003), Aspergillus fumigatus (XP_754048) (Nierman et al., 2005), Neosartorya fischeri (XP_001266052) (direct submission), Aspergillus clavatus (XP_001273916) (direct submission), Aspergillus nidulans (AAM47511) (direct submission), Schizosaccharomyces pombe (Q10063) (Tasaka et al., 2000), Sacccharomyces cerevisiae (BAA06859) (lida et al., 1994) and Claviceps purpurea. Sequence alignment was done with CLUSTAL W of the DNAStar sequence analysis package using standard parameters. Grey shading indicates conserved amino acids; black shading indicates similar amino acids. The four potential transmembrane domains in $\mathrm{Cl}$. purpurea are underlined. + indicates cysteine residues that are believed to be essential for function in Sac. cerevisiae, - those that are dispensable and \pm those that are intermediate according to Maruoka et al. (2002). Diamonds ( $\diamond)$ indicate $N$-glycosylation sites of Sac. cerevisiae Mid1 (lida et al., 1994), of which some are conserved in Cl. purpurea. $\downarrow$ indicates conserved cysteine residues. The tryptophan residue marked with a horizontal arrow indicates the position from which in Sac. cerevisiae a truncation leads to loss of function (Maruoka et al., 2002). 
C. purpurea mid1 10 20 30 40

50

60

70

80 $90 \quad 100$

A. clavatus mid1 ----MQPESTSMRYRLAAILGALIFYSAFLLPER---SFAYASASSSVTWDNQTDAILREDAQPFPYALGSYTGVEIRDVVDENGKARGLD---LVRRVP A. fumigatus mid 1 MQLSMRTDESSMHYLSVAYFGALILLYGPIFLVKKPCLALDPPSDSALLIFSNDTNVILHDVTGOFTSLHGSYSGLDVODTGSENGETRGLD---LVRRVP N. fischeri midl A. nidulans mid N. crassa mid

S. cerevisiae midl S. pombe midl

---MHYLSVAYFGALILLYGPIFLVKSCLALDPPSDPALLISSNDTNVILHDIAEHETFPHGSYSGLEVQDTVSENGETRGLD---LVRRVP ---MQRQNAPAQSREGARVSVTILLAVLISAFATGTDLGPLTSDYGQGRLLAKDDTLGGEPYLIGSFSGLGIDREGDRAREPQGLD---ILNRAS --MHLGLLLRFAASE IALSLLVVENITLFSLDCALAAELEDAPPILILDDVDSDLDVSQGSVSDLGSPLDQMYEPEFAAFDRSIIGRDQV MIVWQALFVVYCLFTTSIHGLFODFNPEANKNISLKFPSLNRWEKNVMATGOOTIIN-

101 110 120 130 140 150 160 170 180 190 200

C. purpurea mid 1 GDTIPLGDEAPLAENLOPGNAPICYIIKKGSLGNSTDPASRKR------------DDDDDDDDDPDDTADASVYEGMNTTMYISANTCLOPKIRPKGN-

A. clavatus midl SGVPSLGNNOYKTSDIKLGEIQWWYEPEESVNGKKANSTTGLP-ERITEGQTSDEAVDSDELRKRDGGLAKRAATVYLSLTMCSKPDVNKTSS-

A. fumigatus midl PGVSSLGNNQEKTSGIKLGETQWWYEPKESVNGKKSNVTSGLP-ERISVDRTSQQTVRSEELRKRDGDTVKRSTSVYLSLTMCSKPDINITNGN. fischeri midl PGVSSLGNNQEKTSGIKLGETQWWYF PKESVNGKKSNVTSELP-------ERISFDGTSQQTVSSDELRKRDGDIVKRSTSVYLSLTMCSKPDINNTNGA. nidulans midl DDRRSLGNNREGESEILMGEILOWLFVPDSTAGNSS--------------------DAQSENISKR------ASTAVYVSLTICSAPILNES---

$N$. crassa mid1 RDTNALINNEAFQLNVRQGDTERFVEKLSQLSERELEVVQLELRDEEHTWËDIDEDEDEDEAEEDEKDENNDDLSGKGLDRDSVDINLASAKQKLGKRQQ S. cerevisiae mid 1 --SDSIYEWTPILSNITAGKKDSFVETIDAEASGYG---------EAPTYEVLMFISGNICQMPMNRSDVDLTIYYSFNETVLENS. pombe midl -----MFEFSTHLILKILFFWSTRRIFGATYTSLLLN------------NTINGNINEQSTAYYNLTWEGNTAYNVSLTLSTCTAFDGAN--

201$$
210 \quad 220 \quad 230 \quad 240
$$

250

260

$$
270
$$

280

290

300

C. purpurea midl --------------DTDKSNKSGPKPPQITMFLSNGTDKDVGCPRITNSTSGEVTQGETAHNEEEGAVTVSLINATTDVYIGIYAPN--IEDDYEGVYN

A. clavatus mid

A. fumigatus mid

N. fischeri mid

A. nidulans mid 1

N. crassa midl

S. cerevisiae mid

S. pombe midl

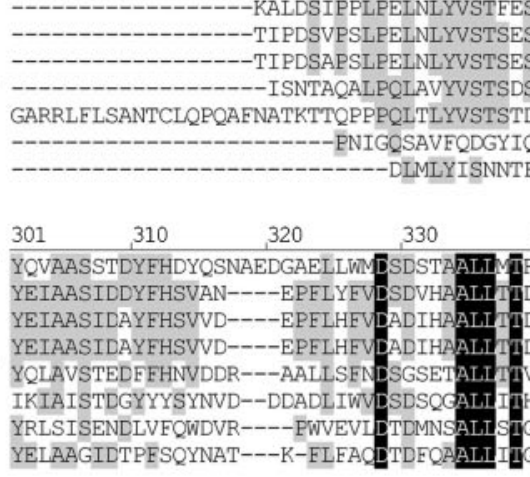

TIPDVPSLPFINIYVSTSESLOKPGPGDDSSK

作 QKVYTAEEGYVATTVE-ASGDVEVGVAVQ---NSTAYSGEYT QEVETADEGYVGASVQ-ADGDVFIGVAVQ---NSTAYSGGYT QEVETADEGYVGASVO-ADGDVFIGVAVQ---NSTAYSGGYT QTVYHSSEGYMSATVS-ATSEVYIAVAAP---SNGNFSGSYS QVSMVENEGAIMYNFT-TTTDVYVGVHAPN--VAEIFDKPYN NATSTYSNI YVVAELVNSTTEOPLSSSDAS--------DNTE LATIFVTGYSPLYIAVSSAFSQEAPNEFVESGESTLEGNNVIN

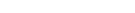

C. purpurea midl

A. fumigatus mid

N. fischeri mid

A. nidulans mid

N. crassa mid

S. cerevisiae midl

$S$. pombe midl

$401 \quad 410 \quad 420 \quad 430$

C. purpurea midl KNNEMVRTSMTLRGP

A. clavatus mid 1 KGDHEVEAGMINRGL-

A. fumigatus midl EGDHGVEGGMTNRGL-

N. fischeri midl EGDHGVEGGMTNRGL--

A. nidulans midl NGHNVEASMSRRKSD

N. crassa midl KYSNMVQTGMTKRGQ-

S. cerevisiae midl -SONTSNATVTSNSTNPLERTDLAIOKKITEYGGSVTF?

S. pombe midl --TNNADRSMTLRGL-------GPFAKE
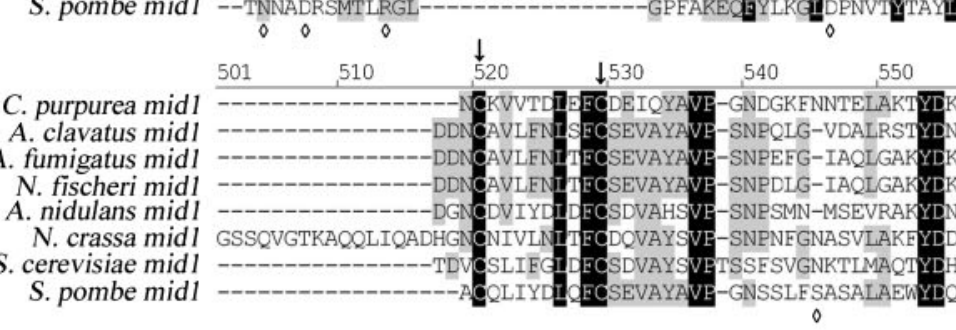
0

360

$\frac{380}{1}$ RNLTDDASETR---EVWSEDPPYQLYVSGQD---WPVLDGLRP DNLTESSAGSENYQQWMNITPPFTMEAHNVN---DTAISGLO DNLTISEEGSENYQQWMNLTPPETMEAHNVN---DTAISGLQP DNLTISEEGSENYQQWMNLTPPETMEAHNVN---DTAISGLQR VSPADEILTEEQRKQWENNTTVYKLFVNNAN---STIGSGLSP HINLTDSNDEKE--QQRIMNTPPYVMEACDKS---NPSINGVRY GNVTADAKVYHNYSIYDPSLYDLYVYSYEDS---VQLNQNYNI GNLTTN--- 0 ETSIIPSYEIYVNPSNSTYDNTENKFS
450

460

470

480

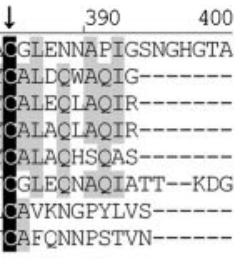

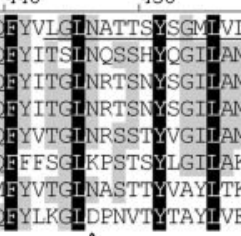

PANTTVNVNRRQDDASGSSRKRGSIVEEG

$490 \quad 500$

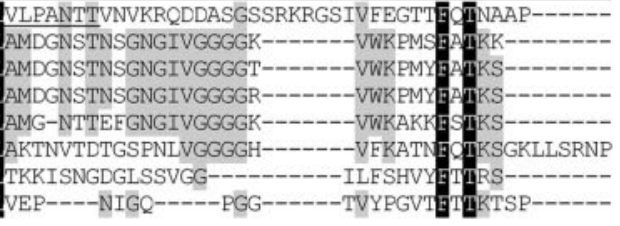

VEP----NIGQ-----PGG------TVYPGVTITIIKTSP------

\section{1}

C. purpurea midl

A. clavatus mid I

A. fumigatus mid 1

N. fischeri midl

A. nidulans mid 1

N. crassa midl

S. cerevisiae midl

S. pombe mid 1

VSI

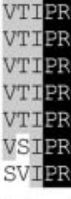

620

630

640
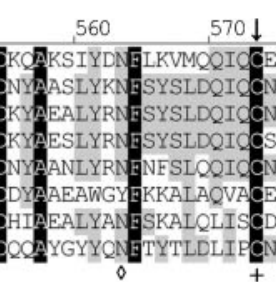

580

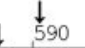

600

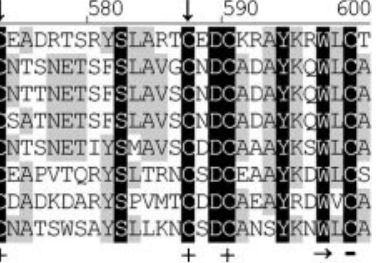

$$
701 \quad 710 \quad 720
$$

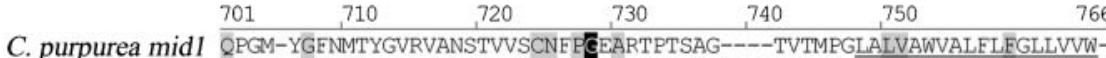

740

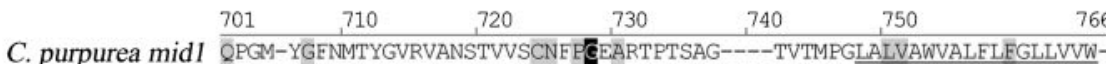

660

670

EF-hand-like structure

$\frac{1}{680}$

690

70

A. clavatus mid1 Q----NGWIDSAYGQRISNSDITCSYB AAYDLNAGW--TLHEPLGVALIALGSEWVSFWEST--

A. fumigatus mid 1 ----GARISSAYGQRGSSSEITCSY EAAYDLNAGR--ARREPLGWLLLAMGSFWFSFWALRVDA

N. fischeri midl 1 ----GTRLNSAYGQRGSSSEITCSYEGAAYDLNAGR--SLREPLGWLLLATGIFWESEWALRVDA

A. nidulans midl S----GKYLTYSYDTSAAPS-

N. crassa mid1 LPGQ-KGFNSSYYIKNETNGEVVCNYE GAHIFSGSSKDAVSVGLTIVVLVLWRRWSFCELGQC--

S. cerevisiae mid1 NDLTTEDLIYQSYNFYMDTDYSTCNYI

S. pombe midl KAG--YGLEFSYGEVSNVTGLITCNAE GVEFYESGSALLNISWRTEFISLIEWILFVE--------

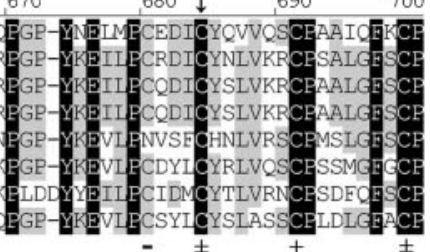


Microscopic analysis. The infected and $\mathrm{KOH} /$ aniline blue-stained ovaries were observed using epifluorescence microscopy (Leica DMRBE), equipped with a PixelFly Digital camera (PCO Computer Optics), using filter block A [excitation filter BP 340-380 (UV light), RKP 400, suppression filter LP 425]. For microscopic analysis of fungal hyphal structure, protoplasts or mycelial fragments of the respective strains were grown on agar-coated slides for $24 \mathrm{~h}$ in glass Petri dishes. CW staining of hyphae was done by incubating the whole slide for $10 \mathrm{~min}$ in $\mathrm{CW}(0.1 \%$, w/v, in $0.1 \mathrm{M}$ Tris/ $\mathrm{HCl} \mathrm{pH} \mathrm{8.5).} \mathrm{Slides}$ were washed twice with distilled water and observed with an inverted microscope (Leica DMIRE2) equipped with a Leica TCS SP2 laserscanning device (Leica Microsystems) using a $40 \times$ (NA 0.8) waterimmersion lens. CW fluorescence was excited using a $405 \mathrm{~nm}$ laser. Fluorescein isothiocyanate-labelled wheatgerm agglutinin (FITCWGA) fluorescence was excited using a $498 \mathrm{~nm}$ laser line. Images were collected with 8-bit resolution using an emission range between 420 and $810 \mathrm{~nm}$ (CW) and 500 and $580 \mathrm{~nm}$ (FITC-WGA) with a frame average of 1 and a line average of 2. Electronic magnification was set at $4.7 \times$. Images are shown as an average of five images.

\section{RESULTS}

\section{Cl. purpurea mid1 encodes a putative stretch- activated, nonselective $\mathrm{Ca}^{2+}$ ion channel}

A 918 bp fragment with high similarity to the mid1 gene of $N$. crassa was obtained from a cDNA clone of an EST library of $\mathrm{Cl}$. purpurea (Oeser et al., 2009) and was used to screen a genomic $\lambda$ library. Homologous fragments were subcloned and sequenced. The midl gene in $\mathrm{Cl}$. purpurea comprised two exons with a total length of $1899 \mathrm{bp}$ and one intron of 117 bp (GenBank accession no. FM945328). The inferred 623 amino acid protein sequence contained all conserved domains typical for Mid1 (Fig. 1): four putative transmembrane domains, multiple $\mathrm{N}$-glycosylation sites and ten conserved cysteine residues, of which four are reported to be essential, three are intermediate (meaning not necessarily important for function) and three are nonessential for function and localization in Sac. cerevisiae (Iida et al., 1994; Maruoka et al., 2002; Ozeki-Miyawaki et al., 2005). Two of four hydrophobic transmembrane domains were located at the $\mathrm{N}$ - and the C-termini. The second hydrophobic domain $\left(\mathrm{E}^{200}\right.$ to $\left.\mathrm{I}^{218}\right)$ matched the third hydrophobic domain (H3) in Sch. pombe $\mathrm{Yam} 8^{+}$and the third hydrophobic domain $\left(\mathrm{L}^{352}\right.$ to $\left.\mathrm{L}^{371}\right)$ matched the fourth hydrophobic domain (H4) in Sac. cerevisiae Mid1 with respect to position. Moreover, a cysteine-rich region at the $\mathrm{C}$-terminus of the protein $\left(\mathrm{C}^{457}\right.$ to $\left.\mathrm{C}^{595}\right)$ is conserved and was shown to play an important role in proteinprotein interactions in Sac. cerevisiae (Iida et al., 1994). According to Maruoka et al. (2002) the Sac. cerevisiae homologue has an EF-hand-like structure spanning from $\mathrm{F}^{408}$ to $\mathrm{V}^{445}$ (corresponding to $\mathrm{F}^{448}$ to $\mathrm{V}^{485}$ in Cl. purpurea; Fig. 1) which includes three conserved cysteine residues $\left(\mathrm{C}^{417}, \mathrm{C}^{431}\right.$ and $\mathrm{C}^{434}$ in Sac. cerevisiae; $\mathrm{C}^{457}, \mathrm{C}^{471}$ and $\mathrm{C}^{474}$ in Cl. purpurea) and which has a very low affinity for $\mathrm{Ca}^{2+}$ binding compared to the reference calmodulin. The region spanning from $\mathrm{L}^{487}$ to $\mathrm{A}^{508}$ (Fig. 1) showed similarity to the S3/H3 hydrophobic region of a superfamily of ion channels that consists of a cGMP-gated channel and several voltage- gated $\mathrm{K}^{+}, \mathrm{Na}^{+}$and $\mathrm{Ca}^{2+}$ channels (Jan \& Jan, 1990). The amino acid sequence of the $\mathrm{Cl}$. purpurea Mid1 showed $40.6 \%$ identity to Sac. cerevisiae Mid1 (GenBank accession no. NP_014108), $48.8 \%$ with N. crassa Mid1 (CAD70927) and $41.9 \%$ to Ca. albicans Mid1 (XP_710952).

\section{Generation of $\Delta$ mid1 mutants}

In order to study the impact of Mid1 on pathogenicity and development of $\mathrm{Cl}$. purpurea, mid1 was deleted by gene replacement (Supplementary Fig. S1a). For this purpose the $5^{\prime}$ - and the $3^{\prime}$-flanking regions were amplified by PCR and subsequently fused to a phleomycin-resistance cassette. The excised replacement fragment was used to transform protoplasts of $\mathrm{Cl}$. purpurea strain $20.1 \Delta k u 70$, a strain with an enhanced homologous recombination rate (Haarmann et al., 2008). Phleomycin-resistant colonies were collected and analysed by diagnostic PCR. Five out of ten independent transformants showed homologous integration of the replacement fragment but - as usual for primary transformants of $\mathrm{Cl}$. purpurea - amplification of the wild-type sequence indicated that these strains were heterokaryotic. A Southern blot experiment using three primary transformants showed a single integration at the designated gene locus as well as a weak wild-type signal (data not shown). Repeated single-spore isolations were performed to obtain homokaryotic deletion mutants, from which three stable homokaryotic deletion mutants were selected, $\Delta$ mid1-1, $\Delta$ mid1-2 and $\Delta$ mid1-3. Each mutant contained the $1.6 \mathrm{~kb}$ PCR fragment specific to the left flank and the $1.3 \mathrm{~kb}$ right flank fragment, but lacked the $0.9 \mathrm{~kb}$ wild-type fragment (mid1; Supplementary Fig. S1b). No wild-type signal was observed in Southern analysis (Supplementary Fig. S1c). Since all transformants showed a similar phenotype in terms of pathogenicity, growth rate and morphology (data not shown), the mutant $\Delta$ mid1-2 was selected for further investigation and for complementation (hereinafter referred to as the $\Delta$ mid1 mutant strain).

\section{Deletion of mid1 leads to a significant growth defect in axenic culture}

The $\Delta$ mid1 mutant showed normal colony morphology compared to $20.1 \Delta k u 70$ on different growth media, but a significantly lower growth rate (Fig. 2a). After 12 days of growth on $\mathrm{MM}$ the mean colony diameter was $63 \pm 0.77 \mathrm{~mm}$ for $20.1 \Delta k u 70$ and $44 \pm 2 \mathrm{~mm}$ for $\Delta$ midl .

In contrast to Sac. cerevisiae (Iida et al., 1994), it was not possible to complement this phenotype by supplementation of the growth medium with higher concentrations of $\mathrm{CaCl}_{2}$ (up to $200 \mathrm{mM}$ ). In fact the growth rate compared to $20.1 \Delta k u 70$ was further reduced by higher $\mathrm{Ca}^{2+}$ concentrations (Supplementary Fig. S2). Similarly, supplementing the medium with $\mathrm{Mg}^{2+}(66 \mathrm{mM})$ decreased the mean growth rate to about $45 \%$ that of $20.1 \Delta k u 70$ $(28.4 \pm 1.72 \mathrm{~mm}$; data not shown). 


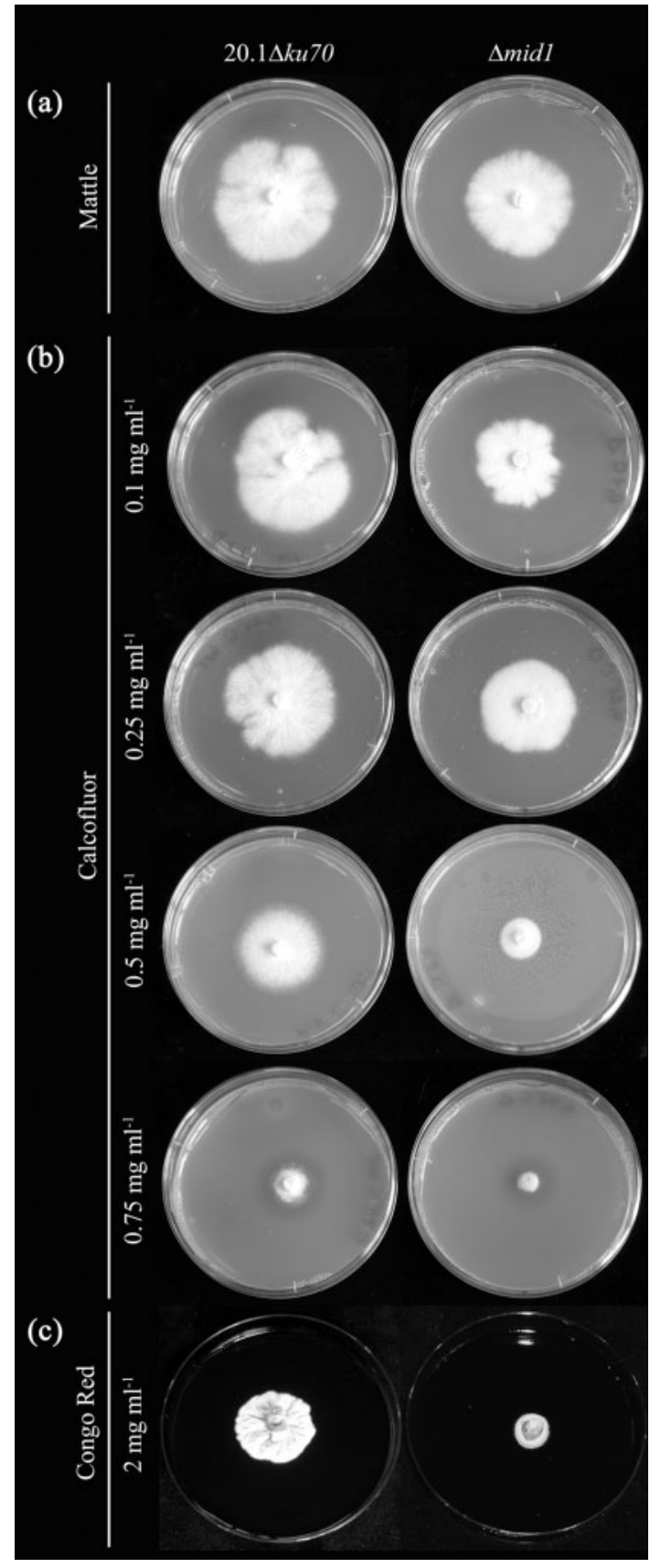

Fig. 2. Colony morphology of $20.1 \Delta k u 70$ and the $\Delta$ mid 1 mutant on MM (a), MM with CW (b) and MM with Congo red (c) after 1 week of growth. In all conditions tested the growth of the $\Delta$ mid1 mutant is reduced compared to that of $20.1 \Delta k u 70$.

The growth defect of $\Delta$ midl could be partially complemented with increased agar concentration in MM (1\%, $1.5 \%, 2 \%, 3 \%$ agar; all w/v, Supplementary Fig. S3). Whereas $20.1 \Delta k u 70$ showed a consistent growth pattern over the four agar densities tested $(44 \pm 1.52 \mathrm{~mm}, 9$ days p.i.), the $\Delta$ midl mutant showed a significantly increased growth rate from $26 \pm 1.41 \mathrm{~mm}$ at $1 \%$ agar to $33 \pm 2 \mathrm{~mm}$ at $3 \%$ agar (Supplementary Fig. S3b). However, increased agar concentration did not lead to the full restoration of $20.1 \Delta k u 70$ growth.

\section{The $\Delta$ mid1 mutant shows higher sensitivity to cell wall stress but not to osmotic stress}

Since Mid1 in other systems is known to be involved in sensitivity to cell wall and osmotic stress, plate assays with standard stressors were performed. Both Congo red (2 mg $\mathrm{ml}^{-1}$; Fig. 2c) and CW (0.1-0.75 $\mathrm{mg} \mathrm{ml}^{-1}$; Fig. 2b), which interfere with cell wall structure, had a significant effect on the growth rate of the $\Delta$ mid1 mutant.

Because of these effects, cell wall morphology was investigated by fluorescence microscopy using CW, a fluorochrome that interacts with several (mostly $\beta-1,4-$ linked) polysaccharides (Maeda \& Ishida, 1967; Pringle, 1991) and can be used to stain the fungal cell wall. Massive aggregations of cell wall polysaccharides were observed randomly distributed over the hyphae of the $\Delta$ mid1 mutant after 10 min incubation in CW solution. In most cases, the septa appeared thicker in the $\Delta$ midl mutant (Fig. 3a). Furthermore, a diffuse accumulation of cell wall material was observed in hyphal tips (Fig. 3c, d). This accumulation was less pronounced in the very tip of growing hyphae of the $\Delta$ mid1 mutant compared to hyphae of $20.1 \Delta k u 70$. In the $\Delta$ mid1 mutant the $\mathrm{CW}$ fluorescence predominantly accumulated in a ring adjacent to the apex (Fig. 3c). Fluorescence microscopy with FITC-WGA, which has a high affinity for $\beta$-linked polymers of $N$-acetylglucosamines like chitin (Meyberg, 1988; Schoffelmeer et al., 1999), suggests that these aggregates do not contain chitin (Fig. 3g, h).

Both $20.1 \Delta k u 70$ and the $\Delta$ mid1 mutant showed a decrease in growth rate under $\mathrm{NaCl}$-induced osmotic stress. However, at concentrations up to $100 \mathrm{mM}$, the growth of $\Delta$ mid1 was actually less impaired than that of $20.1 \Delta k u 70$. Growth rates of both the mutant and $20.1 \Delta k u 70$ were impaired at $0.5 \mathrm{M} \mathrm{NaCl}$, and growth ceased at concentrations in excess of $1 \mathrm{M} \mathrm{NaCl}$ (Supplementary Fig. S4).

\section{Mid1 affects $\mathrm{Ca}^{2+}$ homeostasis}

A plate assay using $\mathrm{MM}$ (without $\mathrm{CaCl}_{2}$ supplementation) and different concentrations of the $\mathrm{Ca}^{2+}$ chelator EGTA $(0,1,5$ and $10 \mathrm{mM})$ revealed that the $\Delta$ mid 1 mutant has a higher tolerance of reduced external $\mathrm{Ca}^{2+}$ concentrations than did 20.1 $\Delta k u 70$. At lower concentrations of EGTA and on plates without $\mathrm{CaCl}_{2}, 20.1 \Delta k u 70$ showed a greater reduction in growth rate than the mutant, while significant growth inhibition in the mutant was only observed at the highest EGTA concentration of $10 \mathrm{mM}$ (Supplementary Fig. S5). Growth of the $\Delta$ mid1 mutant was also inhibited by elevated intracellular $\mathrm{Ca}^{2+}$ concentrations, as shown by growth assays using the ionophore A23187, which increases intracellular $\mathrm{Ca}^{2+}$ levels (Nelson et al., 2004). Filter papers soaked with $9.5 \mathrm{mM}$ ionophore in ethanol were applied to 

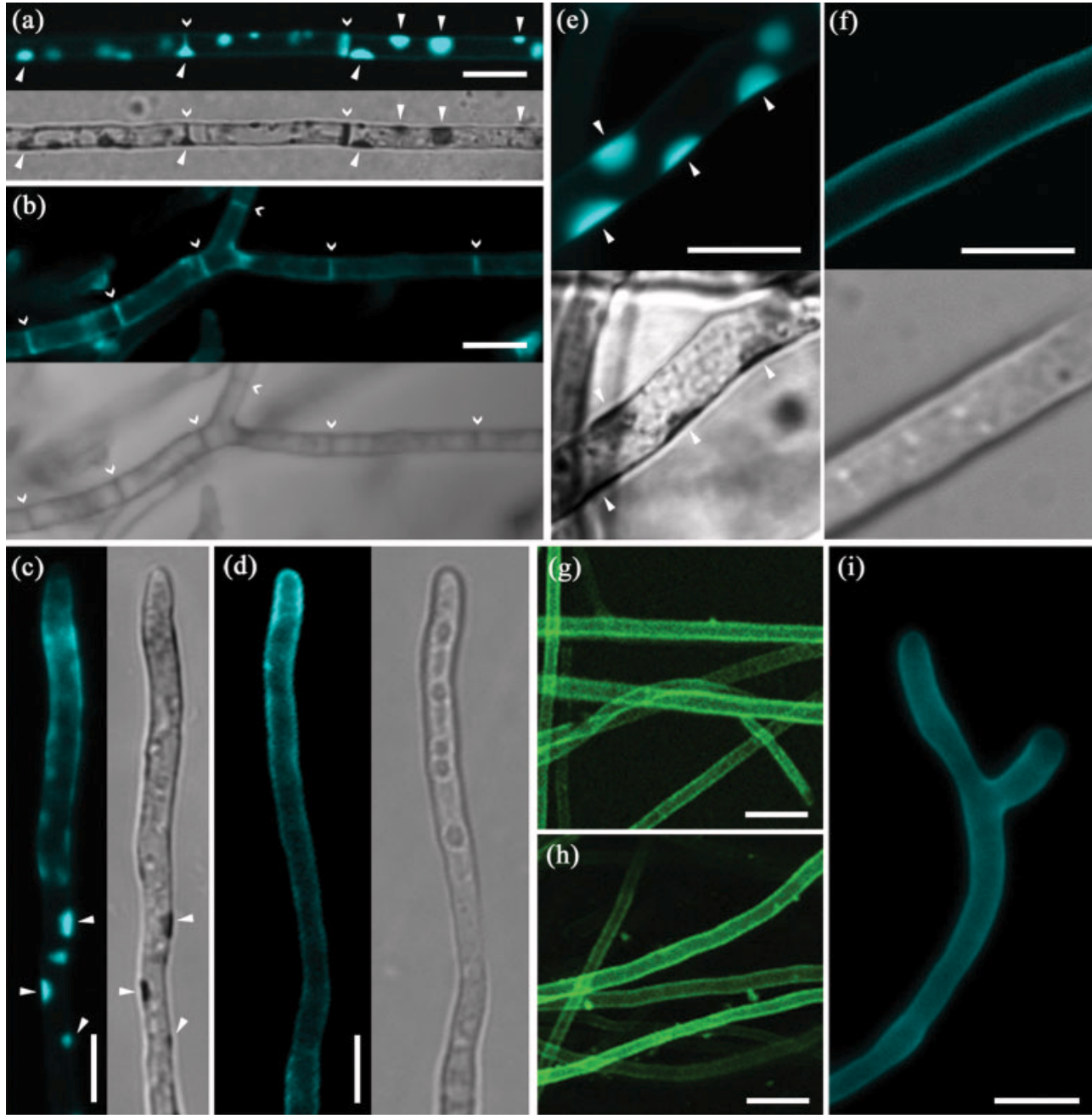

Fig. 3. Confocal laser scanning microscopy: CW and FITC-WGA staining of hyphae of the $\Delta$ mid 1 mutant and $20.1 \Delta k u 70$ in the fluorescence channel and differential interference contrast (DIC). ( $a, b) C W$ fluorescence reveals regular septation (open arrowheads) in both the $\Delta$ mid1 mutant (a) and $20.1 \Delta k u 70$ (b). (a) In the DIC micrograph opaque aggregations (arrowheads) and a thickened septum (open arrow in the middle of the micrograph) can be seen in hyphae of the $\Delta$ mid 1 mutant. CW fluorescence indicates a high content of cell wall polysaccharides in these aggregations. (b) DIC and CW fluorescence show no abnormalities in the distribution of cell wall polysaccharides in 20.1 $\Delta k u 70$. Higher magnifications of CW-stained $\Delta$ mid1 mutant and $20.1 \Delta k u 70$ hyphae are shown in (e) and (f), respectively. (c) A ring of fluorescence accumulation can be seen adjacent to the growing apex of a $\Delta$ mid1 mutant hypha. (d) Fluorescence accumulates at the very tip of a growing hypha of 20.1 $\Delta$ ku70. ( $\mathrm{g}, \mathrm{h})$ FITC-WGA staining shows similar uniform distribution of chitin in hyphae of the $\Delta$ mid1 mutant (g) and $20.1 \Delta k u 70$ (h). (i) $\mathrm{CW}$ staining of a hypha of the complemented $\Delta$ mid1 mutant. Scale bars, $10 \mu \mathrm{m}$.

MM agar plates supplemented with 4.2, 10, 30, 40, 50 and $100 \mathrm{mM} \mathrm{CaCl}_{2}$ and inoculated with $20.1 \Delta k u 70$ and $\Delta$ mid1. After 2 weeks, both $20.1 \Delta k u 70$ and the mutant strain were able to grow towards and across the control filter papers (ethanol only). A zone of inhibition was observed around the ionophore filter papers on plates inoculated with the $\Delta$ mid1 mutant, whereas $20.1 \Delta k u 70$ was able to grow around the paper with little or no inhibition (Fig. 4). The increase in $\mathrm{Ca}^{2+}$ concentration in the medium had no additional impact on the effect of A23187 (data not shown). Both results indicate a role for Cl. purpurea Mid1 in environmental $\mathrm{Ca}^{2+}$ sensing.

\section{The $\Delta$ mid1 mutant is unable to infect rye}

Two types of pathogenicity assays were performed to test the virulence of $\Delta$ mid1 mutant: blooming rye ears or isolated rye ovaries were inoculated with either a suspension of mycelial fragments or with spores of $20.1 \Delta k u 70$ and the $\Delta$ mid1 mutant (Scheffer \& Tudzynski, 


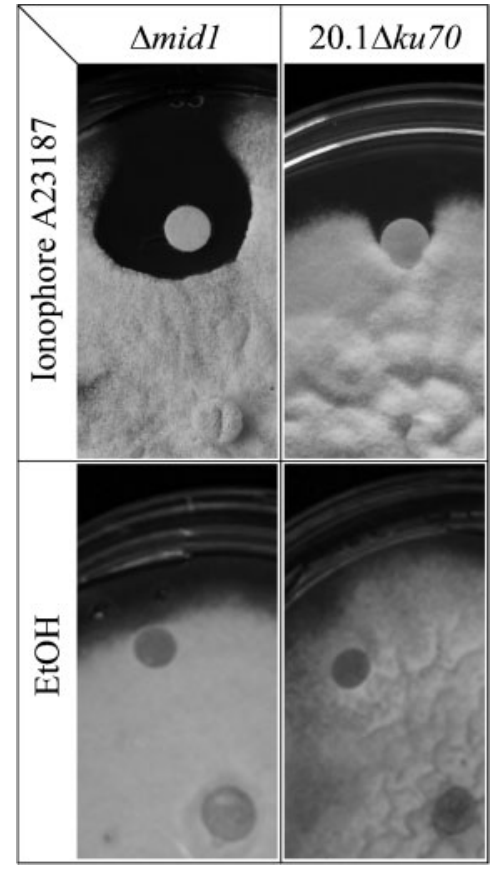

Fig. 4. Effect of the ionophore $\mathrm{A} 23187$ on the growth of $20.1 \Delta k u 70$ and the $\Delta$ mid1 mutant. Colonies were grown for 2 weeks on MM. Filter papers soaked with either ethanol $(\mathrm{EtOH})$ or the ionophore were placed along the growing edge of the colony.

2006). Since the $\Delta$ midl mutant spores show a slightly reduced germination rate, the conidial titre was adjusted in order to ensure that the same amount of viable spores was applied to the plant. In the in planta tests, rye florets infected with $20.1 \Delta k u 70$ spores or mycelial fragments showed a typical infection time-course and development of infection structures (honeydew after $8 \pm 1$ days p.i., sclerotia formation after 16-23 days p.i.). In contrast, rye florets infected with either spores or hyphal fragments of the $\Delta$ midl mutant showed no symptoms of infection. The in vitro infection test confirmed these results. A timecourse experiment showed no sign of infection on isolated ovaries up to 10 days p.i., either in the style or in the transmitting tissue (Fig. 5). Scanning electron microscopy revealed that the $\Delta$ mid1 mutant builds an appressoriumlike structure that is unusual for $\mathrm{Cl}$. purpurea (Fig. 6d). From this structure the fungus grows in many directions, showing hyperbranching across the surface of the rye stigma (Figs $6 \mathrm{~d}$, e and $5 \mathrm{~h}, \mathrm{j}$ ).

These findings strongly suggest that Mid1 is required for invasion of the host tissue and thus represents a pathogenicity factor. To confirm that this phenotype is indeed due to the deletion of midl, the mutant was complemented using the vector $\mathrm{p} 7 \mathrm{cmid} 1$. In the complemented $\Delta$ mid1 mutant, mid1 expression was verified by Northern hybridization (data not shown) and RT-PCR (Supplementary Fig. S1d). The complemented $\Delta$ midl mutant showed normal growth and was able to infect rye ovaries (Fig. 5k). The defect in cell wall composition was also abolished (Fig. 3i).

\section{DISCUSSION}

We have shown that the putative $\mathrm{Ca}^{2+}$ channel Mid1 is essential for penetration of the host tissue by $C l$. purpurea. The penetration defect shown by the $\Delta$ mid1 mutant could be due to disturbed sensing or reduced ability to generate the necessary mechanical force. The thigmotrophic response of Ca. albicans to varying surface contours can be attenuated when gadolinium $\left(\mathrm{Gd}^{3+}\right)$, a blocker of stretch-activated ion channels (Kanzaki et al., 1999; Watts et al., 1998) is applied or the genes proposed to be responsible (Camid1 and Cacch1) are deleted (Watts et al., 1998; Brand et al., 2007). Surprisingly, $\mathrm{Gd}^{3+}$ seems to have no impact on vegetative growth in $\mathrm{Cl}$. purpurea (data not shown); this is in accordance with the findings in N. crassa (Levina et al., 1995). Hence it is likely that membranelocalized stretch-activated $\mathrm{Ca}^{2+}$ channels, and therefore $\mathrm{Ca}^{2+}$ influx, are not essential for tip growth. It is conceivable that mechanical force plays a major role in thigmotropism since the membrane is stretched during invasive growth (Read et al., 1992), whether into agar, a plant cell (e.g $\mathrm{Cl}$. purpurea) or human tissue (e.g Ca. albicans). The slight increase in growth performance of the $\Delta$ mid1 mutant on plates with a higher agar concentration also indicates an involvement of Mid1 in thigmotropism since the fungus is growing on the surface of the agar rather than invading the agar as it would at the lower agar concentration of $1.5 \%$. The deletion of the gene encoding the NDR-like kinase Cot1 in $\mathrm{Cl}$. purpurea led to a growth phenotype comparable to that of $\Delta$ midl (Scheffer et al., 2005). This phenotype could be partially suppressed by the use of a high agar concentration in an overlay, indicating that pressure and mechanical stress also play a role in vegetative growth in $\mathrm{Cl}$. purpurea. In contrast, data from Lew et al. (2008) in N. crassa suggest the opposite conclusion, that harder agar has no impact on growth rate in the $\Delta$ Ncmid1 mutant. However, in addition to the use of a different experimental design, it is also feasible that there is a fundamental difference in Mid1 function between saprophytic and plant-pathogenic fungi. Conflicting results were also obtained for the effects of $\mathrm{Ca}^{2+}$ depletion in the medium: whereas $\mathrm{Ca}^{2+}$ depletion leads to growth arrest in the $N$. crassa mid1 mutant (Lew et al., 2008), the Cl. purpurea mid1 mutant was less sensitive to $\mathrm{Ca}^{2+}$ depletion than $20.1 \Delta k u 70$. In this case it is possible that intracellular $\mathrm{Ca}^{2+}$ stores partially complement the $\mathrm{Ca}^{2+}$ depletion. This assumption is supported by the finding that a reduction of extracellular $\mathrm{Ca}^{2+}$ concentrations by EGTA has almost no effect on the growth rate of the $\Delta$ mid1 mutant up to an EGTA concentration of $5 \mathrm{mM}$. These results suggest that Mid1 plays a role in sensing of both surface characteristics and environmental $\mathrm{Ca}^{2+}$ concentrations. 

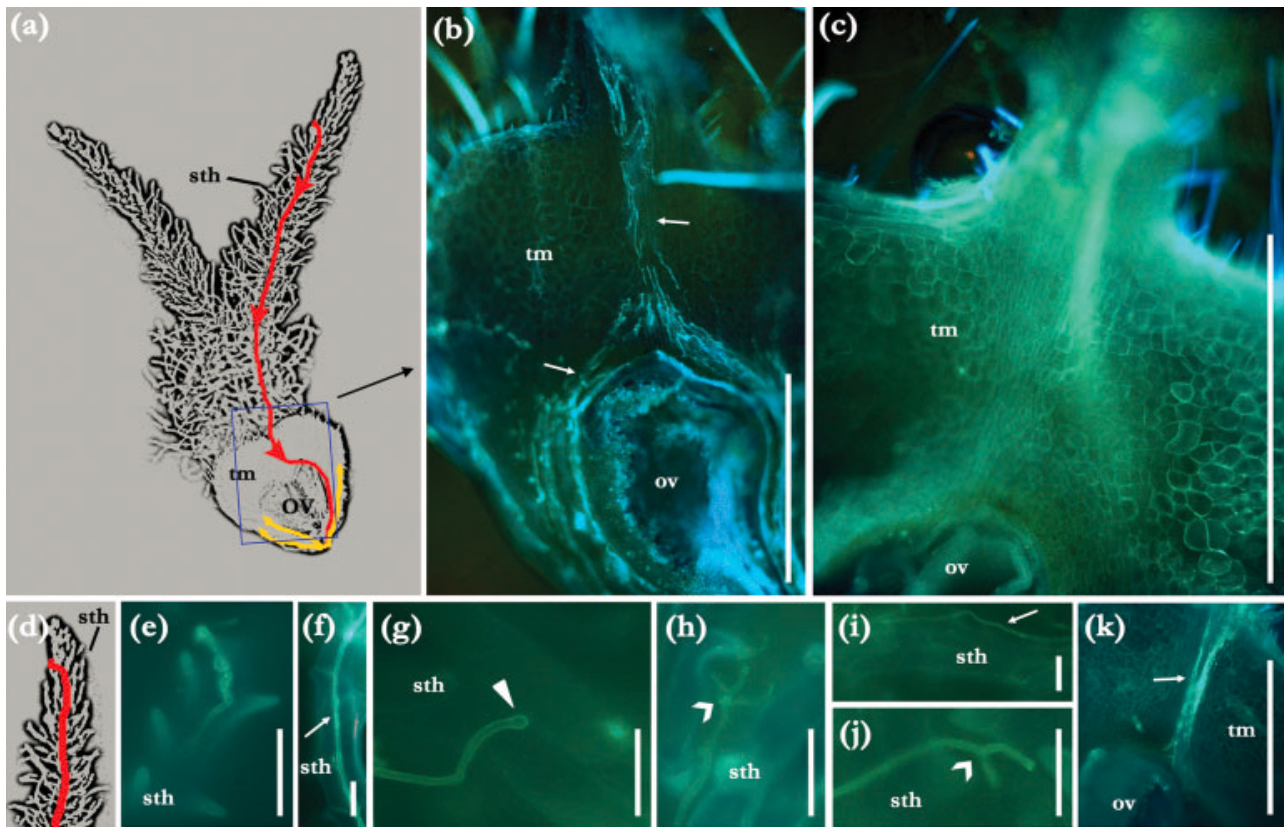

Fig. 5. In vitro pathogenicity test: $\mathrm{KOH} /$ aniline blue staining. (a) Scheme of fungal growth within the rye ovary (6-7 days p.i.). Early infection is shown by red arrows; yellow arrows indicate spreading hyphae starting to colonize the whole ovary after tapping into the vascular bundles of the host plant. The blue box indicates the section shown in (b). (b) Micrograph of an ovary infected with $20.1 \Delta k u 70$ (4 days p.i., assembled picture). The arrows indicate hyphae. (c) Micrograph of an ovary inoculated with the $\Delta$ mid1 mutant (4 days p.i.). (d) Scheme of fungal growth within the rye style. Early infection path is indicated by the red line. (e-j) Stigmatic hairs in higher magnification infected with either $20.1 \Delta k u 70(\mathrm{e}, \mathrm{f})$ or the $\Delta$ mid 1 mutant ( $\mathrm{g}-\mathrm{j})$ of $\mathrm{Cl}$. purpurea. (e) Germinated spore of $20.1 \Delta k u 70$ invading the stigmatic hair. (f) Hypha of $20.1 \Delta k u 70$ growing inside a stigmatic hair (arrow). (g) Hypha of the $\Delta$ mid1 mutant forming an appressorium-like structure (arrowhead). No subsequent invasion of the stigma can be seen. (h) Multiple outgrowths out of an appressorium-like structure (open arrowhead). (i) Hypha of the $\Delta$ mid1 mutant growing over the surface of the stigmatic hair (solid arrowhead). (j) Branching of a hypha growing over a stigmatic hair (open arrowhead). (k) Micrograph of an ovary infected with the complemented $\Delta$ mid1 mutant (5 days p.i., assembled picture). The arrows indicate hyphae. Scale bars: in (b) and (c), $1 \mathrm{~mm}$; in (e-k), $20 \mu \mathrm{m}$. sth, stigmatic hair; tm, transmitting tissue; ov, ovule.

The reduced growth rate in vitro might be due to alterations in the cell wall. The cell wall of yeasts and filamentous fungi consists of a fibrillar network of polysaccharides (the most prominent of which are $\beta-1,3$ glucans) that protects the cell from external stress and also maintains cell shape and flexibility (de Nobel et al., 2001). The reduced accumulation of cell wall polysaccharides in growing tips of the $\Delta$ mid1 mutant may be one explanation for the reduced growth rate. Hyphal elongation depends on accurate transport and deposition of cell wall material towards the growing apex (reviewed by Fischer et al., 2008; Harris \& Momany, 2004). This process seems to be disturbed when mid1 is deleted. Carnero et al. (2000) showed that a mutation in the Sch. pombe homologue of Mid1 (ehs1p) causes an imbalance in the polysaccharide content of the cell wall. The authors observed a more intense CW fluorescence at distinct foci and thickened septa due to an increase in $\beta$-glucan content in the cell wall. Our microscopic observations strongly suggest a comparable modification in the cell wall content of the $\Delta$ midl mutant in $\mathrm{Cl}$. purpurea.
A region of the $C l$. purpurea Mid1 amino acid sequence $\left(\mathrm{F}^{448}\right.$ to $\left.\mathrm{V}^{485}\right)$ shows low similiarity to an EF-hand domain in the Sac. cerevisiae Mid1 protein. In Sac. cerevisiae the comparable region has a low affinity for $\mathrm{Ca}^{2+}$, is needed for Mid 1 function, and is believed to play a role in proteinprotein interactions (Maruoka et al., 2002). Mid1 may interact in vivo with the voltage-gated $\mathrm{Ca}^{2+}$ channel Cch1: it was shown previously that Mid1 either interacts with Cch1 or at least shares functional properties with it, as indicated by knockout of either gene in Ca. albicans (Brand et al., 2007) and Sac. cerevisiae (Fischer et al., 1997; Iida et al., 2004; Paidhungat \& Garrett, 1997).

The $\mathrm{Cl}$. purpurea $\Delta$ mid1 mutant shows a hyperbranching phenotype when growing on the surface of rye florets. It was shown previously that mutation of genes related to calcium signalling often causes hyperbranching of hyphae and hyphal tips (da Silva Ferreira et al., 2007; Prokisch et al., 1997). The same phenotype was observed in Fusarium graminearum when calcium signalling was chemically disrupted (Robson et al., 1991). It seems likely 

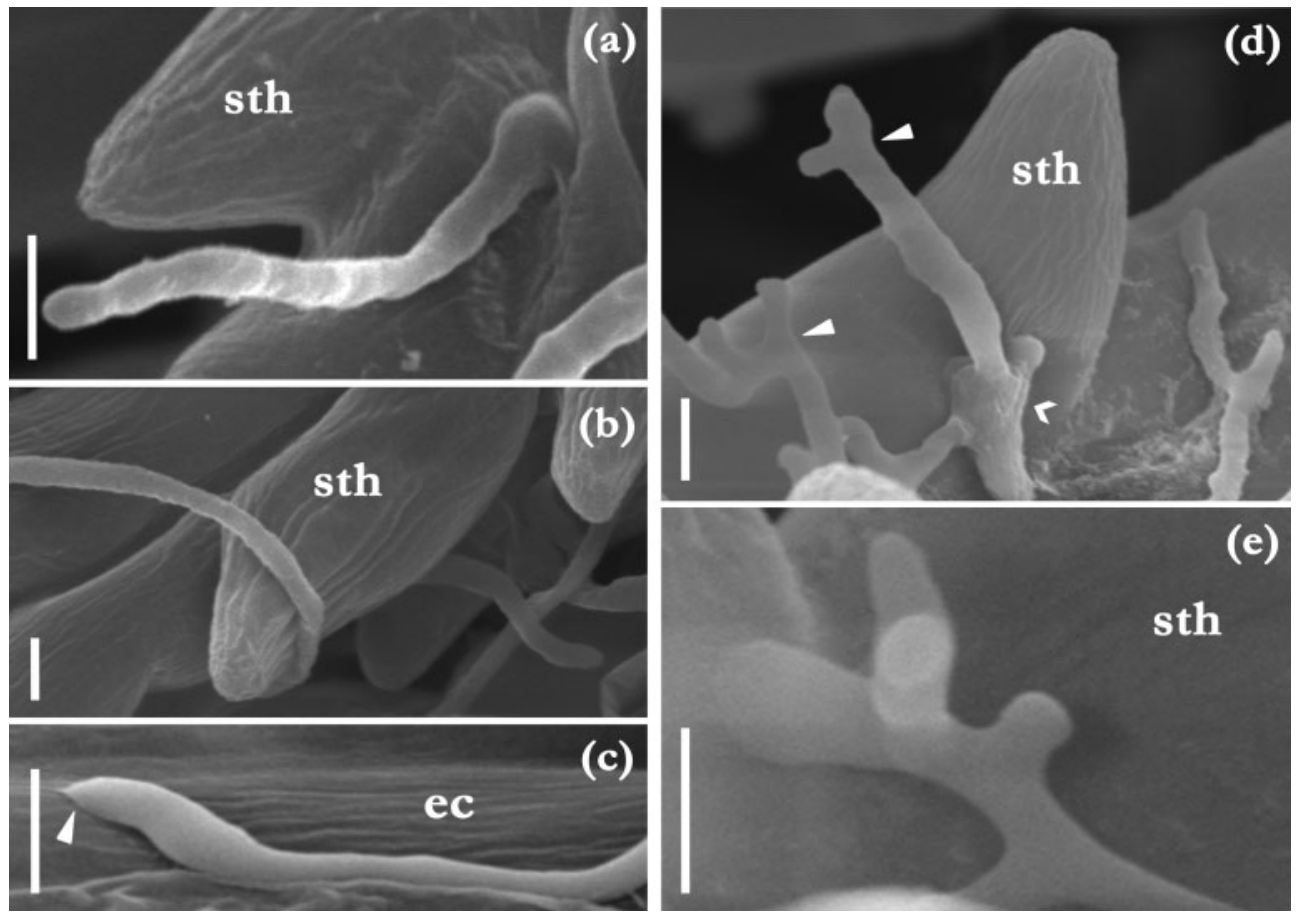

(c)

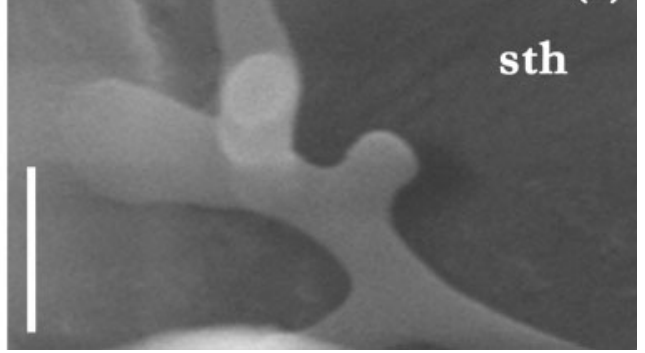

Fig. 6. Scanning electron microscopy of in vitro pathogenicity test. High-resolution images of rye ovaries after infection with $20.1 \Delta k u 70(\mathrm{a}-\mathrm{c})$ or the $\Delta$ mid 1 mutant (d-e). (a) Germinated $20.1 \Delta k u 70$ spore growing on the surface of a stigmatic hair. (b) A $20.1 \Delta k u 70$ hypha growing around a stigmatic hair. (c) A $20.1 \Delta k u 70$ hypha penetrating an epidermal cell of the style (arrowhead). (d) $\Delta$ mid1 mutant growing on the surface of the style and around a stigmatic hair, showing a hyperbranching phenotype. The open arrowhead indicates a swelling of the hyphae at the putative point of attempted penetration (appressorium-like structure) and multiple outgrowths from this structure. The solid arrowhead indicates a hypha with multiple branches. (e) A hypha of the $\Delta$ mid1 mutant showing a hyperbranching phenotype when growing on the surface of a stigmatic hair. Scale bar, $10 \mu \mathrm{m}$. sth, stigmatic hair; ec, epidermal cells.

that in $\mathrm{Cl}$. purpurea a $\mathrm{Ca}^{2+}$ signal is needed to penetrate the plant tissue, and Mid1 is a strong candidate for a role in perception of the signal on the plant surface.

\section{ACKNOWLEDGEMENTS}

We thank Sarah Brown for critical reading of the manuscript, M. Becker for assistance with scanning electron microscopy and the Deutsche Forschungsgemeinschaft (DFG; SFB 629 'Molecular cell dynamics') for financial support.

\section{REFERENCES}

Altschul, S. F., Gish, W., Miller, W., Myers, E. W. \& Lipman, D. J. (1990). Basic local alignment search tool. J Mol Biol 215, 403-410.

Ausubel, F. M., Brent, R., Kingston, R. E., Moore, D. D., Seidman, J. G., Smith, J. A. \& Struhl, K. (1987). Current Protocols in Molecular Biology. New York: Wiley.

Brand, A., Shanks, S., Duncan, V. M., Yang, M., Mackenzie, K. \& Gow, N. A. R. (2007). Hyphal orientation of Candida albicans is regulated by a calcium-dependent mechanism. Curr Biol 17, 347-352.

Carnero, E., Ribas, J. C., García, B., Durán, A. \& Sánchez, Y. (2000). Schizosaccharomyces pombe ehslp is involved in maintaining cell wall integrity and in calcium uptake. Mol Gen Genet 264, 173-183.
Cenis, J. L. (1992). Rapid extraction of fungal DNA for PCR amplification. Nucleic Acids Res 20, 2380.

Currier, H. B. \& Strugger, S. (1956). Aniline blue and fluorescence microscopy of callose in bulb scales of Allium cepa L. Protoplasma 45, 552-559.

Cyert, M. S. (2003). Calcineurin signaling in Saccharomyces cerevisiae: how yeast go crazy in response to stress. Biochem Biophys Res Commun 311, 1143-1150.

da Silva Ferreira, M. E., Heinekamp, T., Härtl, A., Brakhage, A. A., Semighini, C. P., Harris, S. D., Savoldi, M., de Gouvêa, P. F., de Souza Goldman, M. H. \& other authors (2007). Functional characterization of the Aspergillus fumigatus calcineurin. Fungal Genet Biol 44, 219-230.

de Nobel, H., Sietsma, J. H., van den Ende, H. \& Klis, F. M. (2001). Molecular organization and construction of the fungal cell wall. In The Mycota VIII: Biology of the Fungal Cell, pp. 181-200. Edited by R. J. Howard \& N. A. R. Gow. Berlin \& Heidelberg: Springer.

Esser, K. \& Tudzynski, P. (1978). Genetics of the ergot fungus Claviceps purpurea. Theor Appl Genet 53, 145-149.

Fischer, M., Schnell, N., Chattaway, J., Davies, P., Dixon, G. \& Sanders, D. (1997). The Saccharomyces cerevisiae CCH1 gene is involved in calcium influx and mating. FEBS Lett 419, 259-262.

Fischer, R., Zekert, N. \& Takeshita, N. (2008). Polarized growth in fungi - interplay between the cytoskeleton, positional markers and membrane domains. Mol Microbiol 68, 813-826. 
Garrill, A., Jackson, S. L., Lew, R. R. \& Heath, I. B. (1993). Ion channel activity and tip growth: tip-localized stretch-activated channels generate an essential $\mathrm{Ca}^{2+}$ gradient in the oomycete Saprolegnia ferax. Eur J Cell Biol 60, 358-365.

Giesbert, S., Lepping, H. B., Tenberge, K. B. \& Tudzynski, P. (1998). The xylanolytic system of Claviceps purpurea: cytological evidence for secretion of xylanases in infected rye tissue and molecular characterization of two xylanase genes. Phytopathology 88, 1020-1030.

Haarmann, T., Lorenz, N. \& Tudzynski, P. (2008). Use of a nonhomologous end joining deficient strain $(\Delta k u 70)$ of the ergot fungus Claviceps purpurea for identification of a nonribosomal peptide synthetase gene involved in ergotamine biosynthesis. Fungal Genet Biol 45, 35-44.

Hallen, H. E. \& Trail, F. (2008). The L-type calcium ion channel cch1 affects ascospore discharge and mycelial growth in the filamentous fungus Gibberella zeae (anamorph Fusarium graminearum). Eukaryot Cell 7, 415-424.

Harris, S. D. \& Momany, M. (2004). Polarity in filamentous fungi: moving beyond the yeast paradigm. Fungal Genet Biol 41, 391-400.

Hepler, P. K., Vidali, L. \& Cheung, A. Y. (2001). Polarized cell growth in higher plants. Annu Rev Cell Dev Biol 17, 159-187.

Hoagland, D. R. \& Arnon, D. I. (1950). The water-culture method for growing plants without soil. In Agricultural Experimental Station Circular 347. Berkley, CA: College of Agriculture, University of California.

Hood, M. E. \& Shew, H. D. (1996). Applications of KOH-aniline blue fluorescence in the study of plant-fungal interactions. Phytopathology 86, 704-708.

Hüsgen, U., Büttner, P., Müller, U. \& Tudzynski, P. (1999). Variation in karyotype and ploidy level among field isolates of Claviceps purpurea. J Phytopathol 147, 591-597.

lida, H., Nakamura, H., Ono, T., Okumura, M. S. \& Anraku, Y. (1994). MID1, a novel Saccharomyces cerevisiae gene encoding a plasma membrane protein, is required for $\mathrm{Ca}^{2+}$ influx and mating. Mol Cell Biol 14, 8259-8271.

lida, K., Tada, T. \& lida, H. (2004). Molecular cloning in yeast by in vivo homologous recombination of the yeast putative $\alpha 1$ subunit of the voltage-gated calcium channel. FEBS Lett 576, 291-296.

Jackson, S. L. \& Heath, I. B. (1993). Roles of calcium ions in hyphal tip growth. Microbiol Rev 57, 367-382.

Jan, L. Y. \& Jan, Y. N. (1990). A superfamily of ion channels. Nature 345,672 .

Jungehülsing, U., Arntz, C., Smit, R. \& Tudzynski, P. (1994). The Claviceps purpurea glyceraldehyde-3-phosphate dehydrogenase gene: cloning, characterization, and use for the improvement of a dominant selection system. Curr Genet 25, 101-106.

Kanzaki, M., Nagasawa, M., Kojima, I., Sato, C., Naruse, K., Sokabe, M. \& lida, H. (1999). Molecular identification of a eukaryotic, stretchactivated nonselective cation channel. Science 285, 882-886.

Kraus, P. R. \& Heitman, J. (2003). Coping with stress: calmodulin and calcineurin in model and pathogenic fungi. Biochem Biophys Res Commun 311, 1151-1157.

Levina, N. N., Lew, R. R., Hyde, G. J. \& Heath, I. B. (1995). The roles of $\mathrm{Ca}^{2+}$ and plasma membrane ion channels in hyphal tip growth of Neurospora crassa. J Cell Sci 108, 3405-3417.

Lew, R. R., Abbas, Z., Anderca, M. I. \& Free, S. J. (2008). Phenotype of a mechanosensitive channel mutant, mid-1, in a filamentous fungus, Neurospora crassa. Eukaryot Cell 7, 647-655.

Maeda, H. \& Ishida, N. (1967). Specificity of binding of hexopyranosyl polysaccharides with fluorescent brightener. J Biochem 62, 276-278.
Malhó, R. \& Trewavas, A. J. (1996). Localized apical increases of cytosolic free calcium control pollen tube orientation. Plant Cell 8, 1935-1949.

Mantle, P. G. \& Nisbet, L. J. (1976). Differentiation of Claviceps purpurea in axenic culture. J Gen Microbiol 93, 321-334.

Maruoka, T., Nagasoe, Y., Inoue, S., Mori, Y., Goto, J., Ikeda, M. \& lida, H. (2002). Essential hydrophilic carboxyl-terminal regions including cysteine residues of the yeast stretch-activated calciumpermeable channel Mid1. J Biol Chem 277, 11645-11652.

Mattson, M. P. (1999). Establishment and plasticity of neuronal polarity. J Neurosci Res 57, 577-589.

Meyberg, M. (1988). Selective staining of fungal hyphae in parasitic and symbiotic plant-fungus associations. Histochemistry 88, 197-199.

Müller, U., Tenberge, K. B., Oeser, B. \& Tudzynski, P. (1997). Cel1, probably encoding a cellobiohydrolase lacking the substrate binding domain, is expressed in the initial infection phase of Claviceps purpurea on Secale cereale. Mol Plant Microbe Interact 10, 268-279.

Nakagawa, Y., Katagiri, T., Shinozaki, K., Qi, Z., Tatsumi, H., Furuichi, T., Kishigami, A., Sokabe, M., Kojima, I. \& other authors (2007). Arabidopsis plasma membrane protein crucial for $\mathrm{Ca}^{2+}$ influx and touch sensing in roots. Proc Natl Acad Sci U S A 104, 3639-3644.

Nelson, G., Kozlova-Zwinderman, O., Collis, A. J., Knight, M. R., Fincham, J. R., Stanger, C. P., Renwick, A., Hessing, J. G., Punt, P. J. \& other authors (2004). Calcium measurement in living filamentous fungi expressing codon-optimized aequorin. Mol Microbiol 52, 14371450.

Nguyen, Q. B., Kadotani, N., Kasahara, S., Tosa, Y., Mayama, S. \& Nakayashiki, H. (2008). Systematic functional analysis of calciumsignalling proteins in the genome of the rice-blast fungus, Magnaporthe oryzae, using a high-throughput RNA-silencing system. Mol Microbiol 68, 1348-1365.

Nierman, W. C., Pain, A., Anderson, M. J., Wortman, J. R., Kim, H. S., Arroyo, J., Berriman, M., Abe, K., Archer, D. B. \& other authors (2005). Genomic sequence of the pathogenic and allergenic filamentous fungus Aspergillus fumigatus. Nature 438, 1151-1156.

Oeser, B., Heidrich, P. M., Muller, U., Tudzynski, P. \& Tenberge, K. B. (2002). Polygalacturonase is a pathogenicity factor in the Claviceps purpurea/rye interaction. Fungal Genet Biol 36, 176-186.

Oeser, B., Beaussart, F., Haarmann, T., Lorenz, N., Nathues, E., Rolke, Y., Scheffer, J., Weiner, J. \& Tudzynski, P. (2009). Expressed sequence tags from the flower pathogen Claviceps purpurea. Mol Plant Pathol 10, 665-684.

Ozeki-Miyawaki, C., Moriya, Y., Tatsumi, H., lida, H. \& Sokabe, M. (2005). Identification of functional domains of Mid1, a stretchactivated channel component, necessary for localization to the plasma membrane and $\mathrm{Ca}^{2+}$ permeation. Exp Cell Res 311, 84-95.

Paidhungat, M. \& Garrett, S. (1997). A homolog of mammalian, voltage-gated calcium channels mediates yeast pheromone-stimulated $\mathrm{Ca}^{2+}$ uptake and exacerbates the cdc1(Ts) growth defect. Mol Cell Biol 17, 6339-6347.

Pierson, E. S., Miller, D. D., Callaham, D. A., Shipley, A. M., Rivers, B. A., Cresti, M. \& Hepler, P. K. (1994). Pollen tube growth is coupled to the extracellular calcium ion flux and the intracellular calcium gradient: effect of BAPTA-type buffers and hypertonic media. Plant Cell 6, 18151828.

Pringle, J. R. (1991). Staining of bud scars and other cell wall chitin with calcofluor. Methods Enzymol 194, 732-735.

Prokisch, H., Yarden, O., Dieminger, M., Tropschug, M. \& Barthelmess, I. B. (1997). Impairment of calcineurin function in Neurospora crassa reveals its essential role in hyphal growth, morphology and maintenance of the apical $\mathrm{Ca}^{2+}$ gradient. Mol Gen Genet 256, 104-114. 
Read, N. D., Kellock, L. J., Knight, H. \& Trewavas, A. J. (1992) Contact sensing during infection by fungal pathogens. In Perspectives in Plant Cell Recognition, pp. 137-172. Edited by J. A. Callow \& J. R. Green. Cambridge: Cambridge University Press.

Robson, G. D., Wiebe, M. G. \& Trinci, A. P. J. (1991). Involvement of $\mathrm{Ca}^{2+}$ in the regulation of hyphal extension and branching in Fusarium graminearum A 3/5. Exp Mycol 15, 263-272.

Sambrook, J., Fritsch, E. F. \& Maniatis, T. (1989). Molecular Cloning: a Laboratory Manual, 2nd edn. Cold Spring Harbor, NY: Cold Spring Harbor Laboratory.

Schardl, C. L., Panaccione, D. G. \& Tudzynski, P. (2006). Ergot alkaloids - biology and molecular biology. Alkaloids Chem Biol 63, 45-86.

Scheffer, J. \& Tudzynski, P. (2006). In vitro pathogenicity assay for the ergot fungus Claviceps purpurea. Mycol Res 110, 465-470.

Scheffer, J., Ziv, C., Yarden, O. \& Tudzynski, P. (2005). The COT1 homologue CPCOT1 regulates polar growth and branching and is essential for pathogenicity in Claviceps purpurea. Fungal Genet Biol 42, 107-118.

Schoffelmeer, E. A. M., Klis, F. M., Sietsma, J. H. \& Cornelissen, B. J. C. (1999). The cell wall of Fusarium oxysporum. Fungal Genet Biol 27, 275282.

Silverman-Gavrila, L. B. \& Lew, R. R. (2002). An IP3-activated $\mathrm{Ca}^{2+}$ channel regulates fungal tip growth. J Cell Sci 115, 5013-5025.

Silverman-Gavrila, L. B. \& Lew, R. R. (2003). Calcium gradient dependence of Neurospora crassa hyphal growth. Microbiology 149, 2475-2485.

Smit, R. \& Tudzynski, P. (1992). Efficient transformation of Claviceps purpurea using pyrimidine auxotrophic mutants: cloning of the OMP decarboxylase gene. Mol Gen Genet 234, 297-305.
Tasaka, Y., Nakagawa, Y., Sato, C., Mino, M., Uozumi, N., Murata, N., Muto, S. \& lida, H. (2000). yam ${ }^{+}$, a Schizosaccharomyces pombe gene, is a potential homologue of the Saccharomyces cerevisiae MID1 gene encoding a stretch-activated $\mathrm{Ca}^{2+}$-permeable channel. Biochem Biophys Res Commun 269, 265-269.

Tenberge, K. B. (1999). Biology and life strategy of the ergot fungi. VI. Ergot - The Genus Claviceps. In Medicinal \& Aromatic Plants Industrial Profiles, pp. 25-56. Edited by V. Křen \& L. Cvak. Amsterdam \& London: Harwood Academic Publishers.

Tenberge, K. B., Homann, V., Oeser, B. \& Tudzynski, P. (1996). Structure and expression of two polygalacturonase genes of Claviceps purpurea oriented in tandem and cytological evidence for pectinolytic enzyme activity during infection of rye. Phytopathology 86, 10841097.

Torralba, S. \& Heath, I. B. (2001). Cytoskeletal and $\mathrm{Ca}^{2+}$ regulation of hyphal tip growth and initiation. Curr Top Dev Biol 51, 135-187.

Tudzynski, P. \& Scheffer, J. (2004). Claviceps purpurea: molecular aspects of a unique pathogenic lifestyle. Mol Plant Pathol 5, 377-388.

Watts, H. J., Véry, A. A., Perera, T. H., Davies, J. M. \& Gow, N. A. R. (1998). Thigmotropism and stretch-activated channels in the pathogenic fungus Candida albicans. Microbiology 144, 689-695.

Yoshimoto, H., Saltsman, K., Gasch, A. P., Li, H. X., Ogawa, N., Botstein, D., Brown, P. O. \& Cyert, M. S. (2002). Genome-wide analysis of gene expression regulated by the calcineurin/Crzlp signaling pathway in Saccharomyces cerevisiae. J Biol Chem 277, 31079-31088.

Edited by: J. F. Ernst 